\title{
Lifestyle Modification in Patients with Obstructive Sleep Apnea
}

\author{
Jeong-Whun Kim, MD, PhD, Hyun Jung Lim, MD \\ Department of Otorhinolaryngology-Head and Neck Surgery, Seoul National University Bundang Hospital, Seoul National University College of Medicine, \\ Seongnam, Korea
}

\author{
Received: October 8, 2018 \\ Revised: December 13, 2018 \\ Accepted: December 19, 2018 \\ Correspondence \\ Jeong-Whun Kim, MD, PhD \\ Department of Otorhinolaryngology- \\ Head and Neck Surgery, \\ Seoul National University Bundang Hospital, \\ Seoul National University \\ College of Medicine, \\ 82 Gumi-ro 173 Beon-gil, Bundang-gu, \\ Seongnam 13620, Korea \\ Tel +82-31-787-7405 \\ Fax +82-31-787-4057 \\ E-mail kimemails7@gmail.com \\ ORCID \\ Jeong-Whun Kim \\ https://orcid.org/0000-0003-4858-3316 \\ Hyun Jung Lim \\ https://orcid.org/0000-0003-0064-4669
}

Obstructive sleep apnea (OSA) is a disorder in which the upper respiratory tract is closed repeatedly during sleep. Treatment of OSA includes continuous positive airway pressure (CPAP), intraoral devices, and upper respiratory tract surgery, among which CPAP is known as the most effective treatment method. However, even in the case of CPAP, adherence rates during long-term follow-up are lowered considerably due to inconvenience of wearing, and low adherence rates limit its therapeutic effect. Therefore, studies have been carried out to confirm the effect of lifestyle modification which corrects modifiable risk factors of OSA, such as obesity. The aim of this study was to examine the effects of weight loss and aerobic exercise to improve the severity of OSA, and to examine the effect of drinking and smoking on OSA. In consideration of the difficulty of modifying one's lifestyle through traditional individual counseling, we propose the use of smart devices in the management of patients' lifestyles.

Sleep Med Res 2018;9(2):63-72

\section{INTRODUCTION}

Obstructive sleep apnea (OSA) is a disorder in which the upper airway obstruction is repeated during sleep. If left untreated, it causes hypoxia, daytime sleepiness, loss of concentration that can result in traffic and other accidents in the short term, and complications such as high blood pressure [1], cardiovascular disease [2], dementia [3], and depression [4] in the long run.

Obesity, age, male gender, alcohol consumption, and upper airway collapsibility are well known risk factors for OSA, and cigarette smoking has been reported to increase the risk of OSA [5]. Obesity is one of the most important risk factors for OSA, and the incidence and severity of OSA has been positively correlated with body mass index (BMI) [6]. The prevalence of OSA in obese people was shown to be twice that of normal weight people, and a $10 \%$ increase in body weight increased the apnea-hypopnea index (AHI) by 32\% [7].

The most common treatment method for OSA is continuous positive airway pressure (CPAP), intraoral devices, and upper airway surgery. Among them, CPAP maintains an open airway during sleep and is known as the most effective treatment method for improving AHI and daytime sleepiness [8]. The American Academy of Sleep Medicine recommends a CPAP or oral device for the treatment of mild-to-moderate OSA patients. For patients with severe OSA, CPAP is recommended as the first-line treatment and an intraoral device is recommended as a secondary treatment method [9]. However, even among CPAP users, adherence rates during long-term follow-up were low due to inconvenience of wearing, and these low adherence rates limited the therapeutic effectiveness of CPAP [10].

Evidence suggests that weight loss or exercise may reduce the severity of OSA, and drinking and smoking have been found to be associated with an increased risk of OSA. Therefore, behavioral therapy through lifestyle modification as a means to treat OSA was investigated in 
this study. We will discuss lifestyle modification as a treatment method of OSA by examining the results of research on each modifiable item, including weight loss, exercise, alcohol consumption and smoking.

\section{WEIGHT LOSS AS A TREATMENT FOR OBSTRUCTIVE SLEEP APNEA}

Many studies (Table 1) on weight-loss attempts in patients with OSA used a very low-calorie diet of only $600-800 \mathrm{kcal}$ a day for the first 8 to 12 weeks, followed by diet consultation [7,11-17]. In a study of weight loss in patients with mild OSA for one year, a 10\% reduction in average body weight (from 101.2 to $90.5 \mathrm{~kg}$ ) reduced AHI by approximately 40\% (from 10 to 6 events/h). Since the subjects had mild OSA patients, approximately $60 \%$ of the patients were cured with weight loss alone [15]. Despite the fact that there was no further consultation or intervention for one year thereafter, at 2-year follow-up the average BMI of patients decreased further from $-3.5 \mathrm{~kg} / \mathrm{m}^{2}$ (at 1-year follow-up) to $-2.5 \mathrm{~kg} / \mathrm{m}^{2}$ (at 2-year follow-up), and the average decrease of AHI was maintained at -4.0 events/h (at 1-year follow-up) and -4.6 events/h (at 2-year follow-up) [13]. In a study of weight loss during one year in moderate-to-severe OSA patients, AHI decreased by about $16.9 \%$ (from 42.5 to 32.0 events/h) with a $2.2 \mathrm{~kg} / \mathrm{m}^{2}$ reduction in BMI (from 29.8 to $27.6 \mathrm{~kg} / \mathrm{m}^{2}$ ) [11]. In addition, a meta-analysis of studies examining the effects of weight loss on OSA showed that weight loss reduced the severity of OSA [18].

When the mechanism of weight loss to improve severity of OSA was examined, weight loss was found to increase the area of the upper airway by reducing velopharyngeal fat and alleviate collapsing of the upper airway by reducing mechanical burden. In addition, accumulation of abdominal visceral fat due to obesity makes ventilation difficult by increasing abdominal pressure. Weight loss can improve the severity of OSA by reducing abdominal pressure and improving thoracic exercise and ventilation. Some studies have reported that weight loss contributes to the normalization of neuromechanical control of the upper airway during sleep by reducing fat-induced inflammationrelated cytokines, and resolving hormone control disorders caused by obesity $[19,20]$.

\section{AEROBIC EXERCISE AS A TREATMENT FOR OBSTRUCTIVE SLEEP APNEA}

When studies on the effects of weight-loss in patients with OSA were examined (Table 2), moderate-intensity aerobic exercise was performed 3-4 times a week for about 30 to $45 \mathrm{~min}$ utes for 3 months in many cases [21-25]. In a study of threemonth aerobic exercise in patients with mild-to-moderate OSA, there was no reduction in body weight, but AHI decreased by about $28 \%$ (from 15.19 to 11.01 events/h) [23]. In a study of aerobic exercise for 3 months in patients with chronic heart failure, there was no weight loss but AHI decreased by $34 \%$ (from 25.2 to 16.7 events/h), and the sleep efficiency increased by $7 \%$ (from 74.4 to $79.6 \%$ ) [22]. And in a study of 4-week exercise in patients with moderate-to-severe OSA and coronary artery disease, AHI decreased by $34 \%$ (from 31.1 to 20.5 events $/ \mathrm{h}$ ), overnight change in leg fluid volume decreased by $20 \%$ (from -579.0 to $-465.8 \mathrm{~mL}$ ), and overnight change in upper airway cross-sectional area increased from $-0.2 \mathrm{~cm}^{2}$ to $+0.09 \mathrm{~cm}^{2}$ [21]

Although exercise is one method of reducing body weight among life style-related treatment methods, meta-analysis of studies on the effects of aerobic exercise on OSA showed that the effects of exercise were not limited to weight loss [26,27]. In the meta-studies, there was no significant weight loss due to exercise, but AHI in patients with OSA decreased, and sleep efficiency and daytime sleepiness were improved. This means that exercise itself has a therapeutic role in OSA treatment. In dog studies, stimulation of the gastrocnemius muscle and sciatic nerve increased the activity of the genioglossus muscle [28]. In human studies, results have shown that exercise was associated with increased respiratory muscle strength [26,29]. Exercise has also been reported to reduce the fluid retention in the legs, thereby preventing rostral fluid shift to the upper body at night, where it can cause collapse of the upper airway during sleep $[21,30]$. The effect of exercise on OSA appears to be due to the interaction of these multiple mechanisms, rather than the effect of only one of these mechanisms.

\section{EFFECTS OF ALCOHOL INTAKE ON OBSTRUCTIVE SLEEP APNEA}

Table 3 shows that the risk of OSA was about 1.36 to 1.56 times higher for persons who consumed alcohol than for those who did not [31-34]. In a study of 20 healthy men who consumed an excess of $1 \mathrm{~g}$ of alcohol per body weight, alcohol intake increased the frequency of apnea from 20 to 110 times over the entire night's sleep, while desaturation events increased from 118 to 226 times [35]. In a study in which $0.5 \mathrm{~g}$ of alcohol was consumed per body weight in patients with mild-to-moderate OSA, there was no increase in the length of the apnea or aggravation of hypoxia, but the AHI increased by $37 \%$ (from 7.1 to 9.7 events/h) [36]. In a meta-analysis of studies dealing with the association between alcohol and OSA, the risk of having OSA increased by about $25 \%$ from alcohol consumption [37].

The mechanism by which alcohol induces OSA is through lowering genioglossus and hypoglossal motor nerve activities [38,39], decreased sleep arousal [35], increased nasal mucosal swelling, and increased nasal resistance [39]. In addition, alcohol is known to cause segmented sleep regardless of sleep apnea 


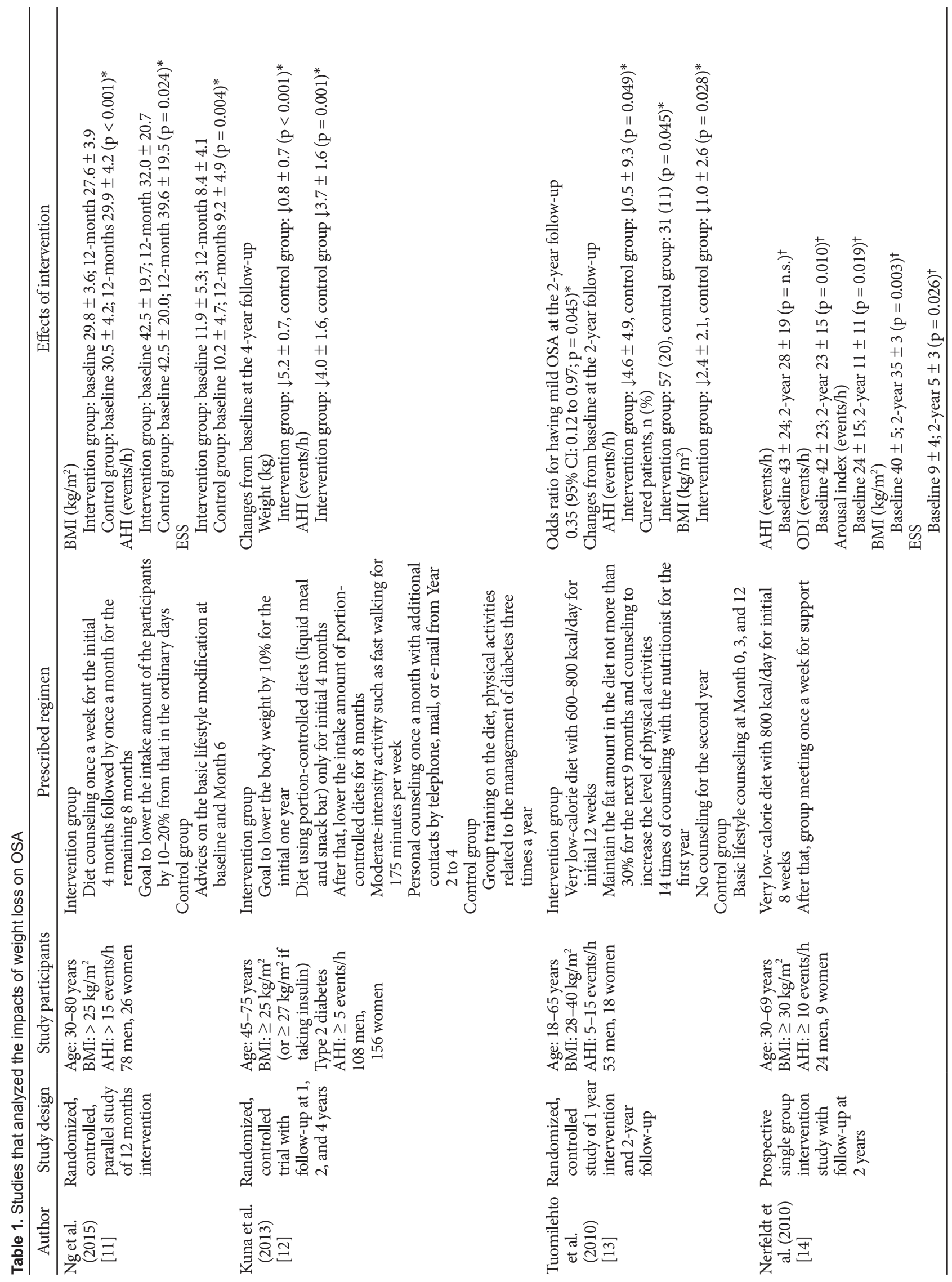




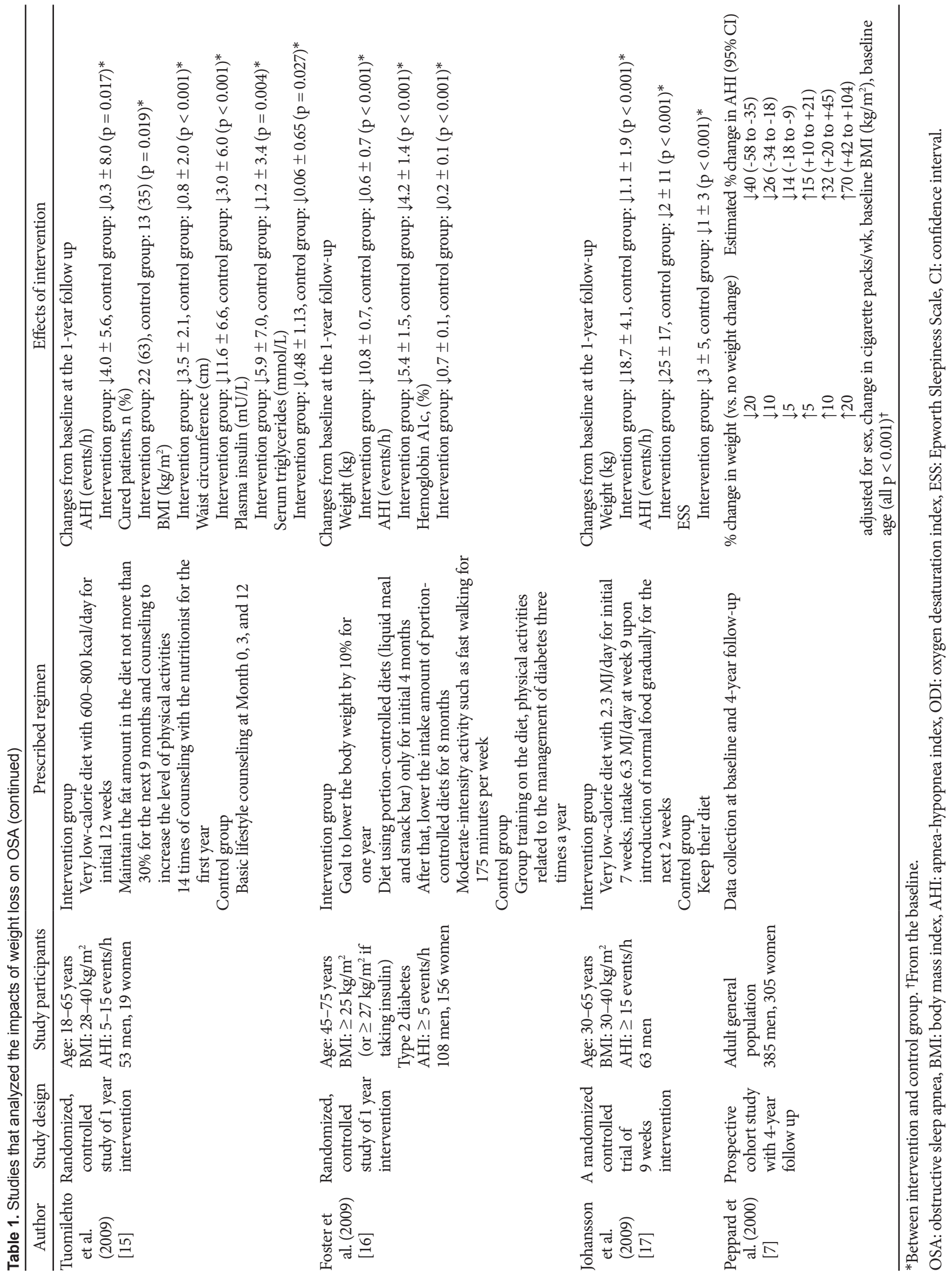




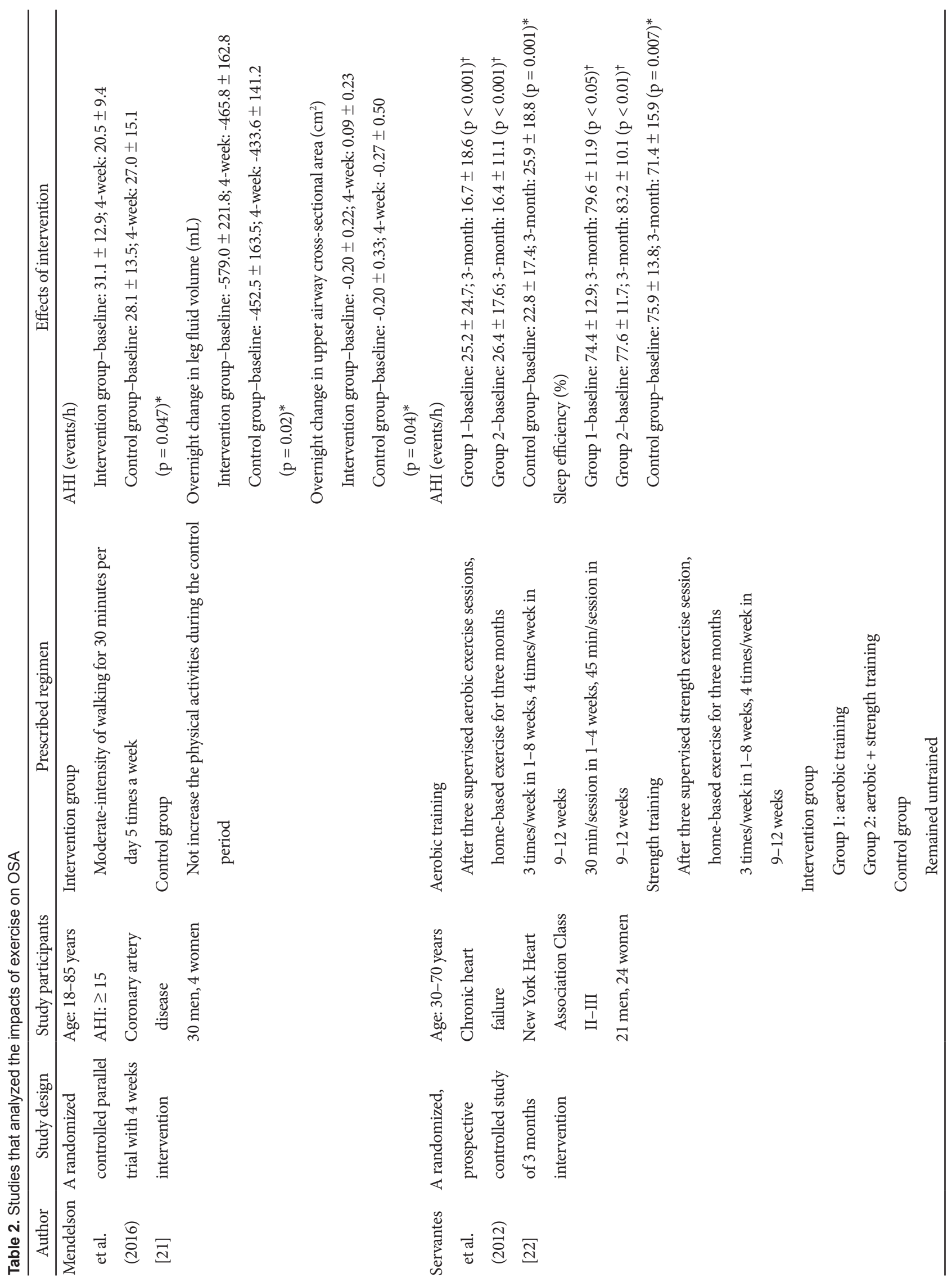




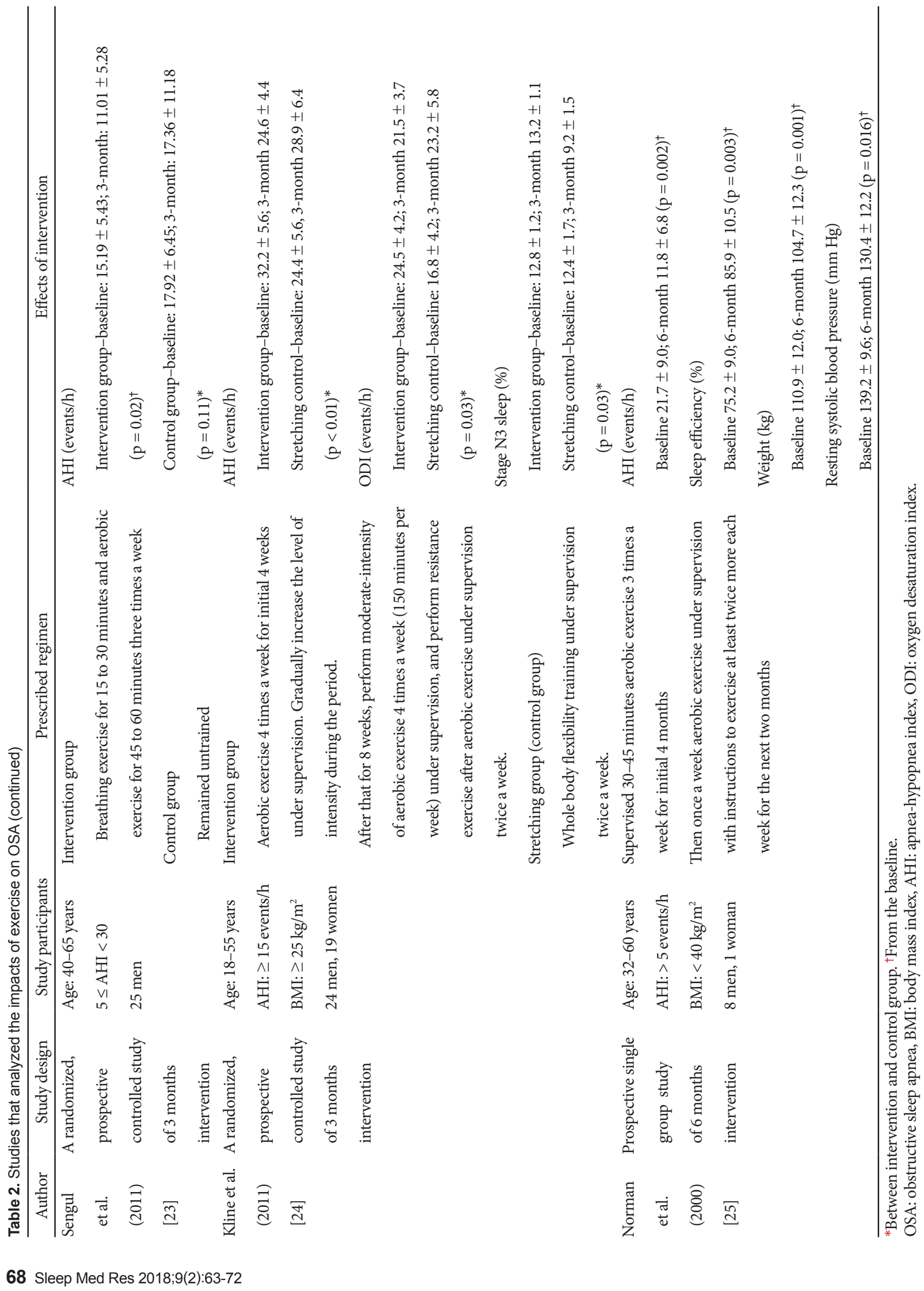


Table 3. Studies that analyzed the impacts of alcohol drinking on OSA

\begin{tabular}{|c|c|c|c|c|c|}
\hline Author & $\begin{array}{l}\text { Study } \\
\text { design }\end{array}$ & $\begin{array}{c}\text { Study } \\
\text { participants }\end{array}$ & Alcohol definition & Adjustment & Adjusted OR (95\% CI) \\
\hline $\begin{array}{l}\text { Baik et al. } \\
\text { (2015) } \\
{[31]}\end{array}$ & $\begin{array}{l}\text { Case } \\
\text { control }\end{array}$ & $\begin{array}{l}\text { Age: } 40-69 \text { years } \\
\text { General } \\
\text { population } \\
956 \text { men, } 807 \\
\text { women }\end{array}$ & $\begin{array}{l}\text { Current drinker vs. } \\
\text { no drinker }\end{array}$ & $\begin{array}{l}\text { NRG1 genotype, age, sex, } \\
\text { BMI, neck circumference }\end{array}$ & $\begin{array}{l}\text { Current drinker: } 1.36(0.97-1.91) \\
\quad(\mathrm{p}<0.05)\end{array}$ \\
\hline $\begin{array}{l}\text { Pan et al. } \\
\qquad(2014) \\
{[32]}\end{array}$ & $\begin{array}{l}\text { Cross } \\
\text { sectional }\end{array}$ & $\begin{array}{l}\text { Age: } \geq 18 \text { years } \\
\text { General } \\
\text { population } \\
18,186 \text { men } \\
20,452 \text { women }\end{array}$ & $\begin{array}{l}\text { Never drinker: never } \\
\text { alcohol use } \\
\text { Current drinker: alcohol } \\
\text { use within the last } 12 \\
\text { months } \\
\text { Past drinker: alcohol use } \\
\text { more than } 12 \text { months } \\
\text { ago }\end{array}$ & $\begin{array}{l}\text { Age, sex, race, marital status, } \\
\text { income, education, asthma, } \\
\text { diabetes, hypertension }\end{array}$ & $\begin{array}{l}\text { Current drinker: } 1.52(1.03-2.23) \\
\quad(\mathrm{p}=0.0329) \\
\text { Past drinker: } 1.65(1.09-2.49) \\
\quad(\mathrm{p}=0.017)\end{array}$ \\
\hline $\begin{array}{l}\text { Kang et al. } \\
\text { (2014) } \\
{[33]}\end{array}$ & $\begin{array}{l}\text { Cross } \\
\text { sectional }\end{array}$ & $\begin{array}{l}\text { Age: } \geq 19 \text { years } \\
\text { General } \\
\text { population } \\
\text { 3,559 men } \\
\text { 4,396 women }\end{array}$ & $\begin{array}{l}\text { Harmful alcohol use vs. } \\
\text { no harmful alcohol use }\end{array}$ & $\begin{array}{l}\text { Age, sex, marital status, } \\
\text { educational level, } \\
\text { occupation, shift work, } \\
\text { smoking, exercise, } \\
\text { musculoskeletal disease, } \\
\text { diabetes mellitus, } \\
\text { hypertension }\end{array}$ & $\begin{array}{l}\text { Harmful alcohol use: } \\
1.566(1.302-1.884) \\
(p<0.001)\end{array}$ \\
\hline $\begin{array}{l}\text { Peppard } \\
\text { et al. } \\
(2007) \\
{[34]}\end{array}$ & Cohort & $\begin{array}{l}\text { Age: } 30-60 \text { years } \\
\text { General } \\
\text { population } \\
775 \text { men, } \\
645 \text { women }\end{array}$ & $\begin{array}{l}\text { Drinks per day } \\
0 \text { drinks: nondrinkers } \\
1 \text { drink: } 0<\text { and }<1 \\
\text { drink/day } \\
2 \text { drinks: } 1 \leq \text { and }<2 \\
\text { drinks/day } \\
3 \text { drinks: } 2 \leq \text { and }<6 \\
\text { drinks/day }\end{array}$ & $\begin{array}{l}\text { Age, BMI, neck, } \\
\text { circumference, waist } \\
\text { circumference, smoking, } \\
\text { antidepressant, } \\
\text { antihypertensive, } \\
\text { cholesterol-lowering } \\
\text { medication use }\end{array}$ & $\begin{array}{l}\text { Men } \\
0 \text { drinks } 1.0 \text { (reference) } \\
1 \text { drink } 1.25(1.07-1.46) \\
2 \text { drinks } 1.55(1.14-2.12) \\
3 \text { drinks } 1.94(1.21-3.09) \\
\quad(\mathrm{p}=0.006) \\
\text { Women } \\
0 \text { drinks } 1.0 \text { (reference) } \\
1 \text { drink } 0.94(0.67-1.33) \\
2 \text { drinks } 0.89(0.45-1.76) \\
3 \text { drinks } 0.83(0.30-2.33) \\
\quad(\mathrm{p}=0.73)\end{array}$ \\
\hline
\end{tabular}

OSA: obstructive sleep apnea, BMI: body mass index, NRG 1: neuregulin 1, OR: odds ratio, CI: confidence interval.

[40], and this increase in segmented sleeping by alcohol exacerbates OSA.

\section{EFFECTS OF SMOKING ON OBSTRUCTIVE SLEEP APNEA}

Some studies have reported that smoking increased the risk of OSA, but other studies have reported that smoking did not increase, or even decreased the risk (Table 4) [41-44]. However, in the Wisconsin sleep cohort study, one of the largest cohort studies of OSA in the United States, smokers were twice as likely to have OSA compared to non-smokers. The amount of smoking and the prevalence of apnea were positively correlated, and those who smoked more than 2 packs per day had a 6.7-fold risk of having mild OSA and a 40-fold risk of having moderate-tosevere OSA [44].

The mechanisms by which smoking may exacerbate OSA include changes in sleep architecture, relaxation of the upper airway muscles and decreased nerve response by nicotine, increased sleep arousal, and increased mucosal inflammation due to smoke aspiration [45]. In a study comparing the uvular mucosa of smokers and non-smokers with OSA who received uvulopalatopharyngoplasty, secretion of calcitonin gene-related peptide (inflammatory mediator) in smoker's mucosa, lamina propria edema, and mucosal thickness were increased, and this mechanism caused smoking to narrow the area of the upper airway and exacerbate OSA [46]. 


\section{CURRENT STATE OF LIFESTYLE MODIFICATION AS A TREATMENT FOR OBSTRUCTIVE SLEEP APNEA}

Previous research has found that weight loss and exercise decreased the severity of OSA, and that alcohol and smoking increased the risk of OSA. Based on these findings, lifestyle modifications of weight loss, aerobic exercise, alcohol abstinence and smoking cessation are effective treatments for OSA (Fig. 1). However, lifestyle modification usually requires frequent individual counseling sessions to increase patient compliance, which is time consuming and costly. Despite the importance of lifestyle modification, in reality, patients with OSA are only counseled or encouraged to make lifestyle changes, and successful lifestyle modification cannot be achieved in this way.

Table 4. Studies that analyzed the impacts of smoking on OSA

\begin{tabular}{|c|c|c|c|c|c|}
\hline Author & Study design & Study participants & Smoking definition & Adjustment & OR $(95 \%$ CI $)$ \\
\hline $\begin{array}{l}\text { Ye et al. } \\
(2014) \\
{[41]}\end{array}$ & $\begin{array}{l}\text { A cross- } \\
\text { sectional } \\
\text { design }\end{array}$ & $\begin{array}{l}\text { Age: } 30-55 \text { years } \\
\text { General population } \\
137 \text { men, } 61 \text { women }\end{array}$ & $\begin{array}{l}\text { Current smoker vs. } \\
\text { no smokers }\end{array}$ & $\begin{array}{l}\text { res13170573 genotypes, } \\
\text { age, sex, BMI, LDL, } \\
\text { hypertension }\end{array}$ & $\begin{array}{l}\text { Adjusted OR } \\
\quad \text { Smokers } 1.32(1.03-2.78)\end{array}$ \\
\hline $\begin{array}{l}\text { Koyama et } \\
\text { al. }(2012) \\
{[42]}\end{array}$ & $\begin{array}{l}\text { A cross- } \\
\text { sectional } \\
\text { design }\end{array}$ & $\begin{array}{l}\text { General population } \\
745 \text { men }\end{array}$ & $\begin{array}{l}\text { Current smoker vs. } \\
\text { no smokers }\end{array}$ & - & $\begin{array}{l}\text { Unadjusted OR } \\
\quad \text { Smokers } 0.74(0.45-1.22)\end{array}$ \\
\hline $\begin{array}{l}\text { Kashyap et } \\
\text { al. (2001) } \\
{[43]}\end{array}$ & $\begin{array}{l}\text { A cross- } \\
\text { sectional } \\
\text { design }\end{array}$ & $\begin{array}{l}\text { Patients who had their } \\
\text { polysomnography } \\
\text { data at sleep center } \\
126 \text { men, } 88 \text { women }\end{array}$ & $\begin{array}{l}\text { Current, never, } \\
\text { former smoker }\end{array}$ & $\begin{array}{l}\text { Age, sex, BMI, and } \\
\text { number of alcoholic } \\
\text { drinks/week. }\end{array}$ & $\begin{array}{l}\text { Adjusted OR } \\
\text { Current vs. never smoker } \\
2.8(1.2-6.5)(\mathrm{p}=0.015) \\
\text { Current vs. never or former smoker } \\
2.7(1.2-5.7)(\mathrm{p}=0.011)\end{array}$ \\
\hline $\begin{array}{l}\text { Wetter et } \\
\text { al. (1994) } \\
{[44]}\end{array}$ & Cohort study & $\begin{array}{l}\text { General population } \\
468 \text { men, } 343 \text { women }\end{array}$ & $\begin{array}{l}\text { Current, never, } \\
\text { former smoker }\end{array}$ & $\begin{array}{l}\text { Sex, education, age, } \\
\text { BMI, number of cans } \\
\text { of caffeinated soda/ } \\
\text { day, number of cups } \\
\text { of caffeinated coffee } \\
\text { or tea/day, number of } \\
\text { alcoholic drinks/week }\end{array}$ & $\begin{array}{l}\text { Adjusted OR } \\
\text { Current vs. never smoker } \\
3.05 \text { (1.44-6.44) } \\
\text { Former vs. never smoker } \\
1.33(0.77-2.30)\end{array}$ \\
\hline
\end{tabular}

OSA: obstructive sleep apnea, BMI: body mass index, LDL: low-density lipoprotein, OR: odds ratio, CI: confidence interval.

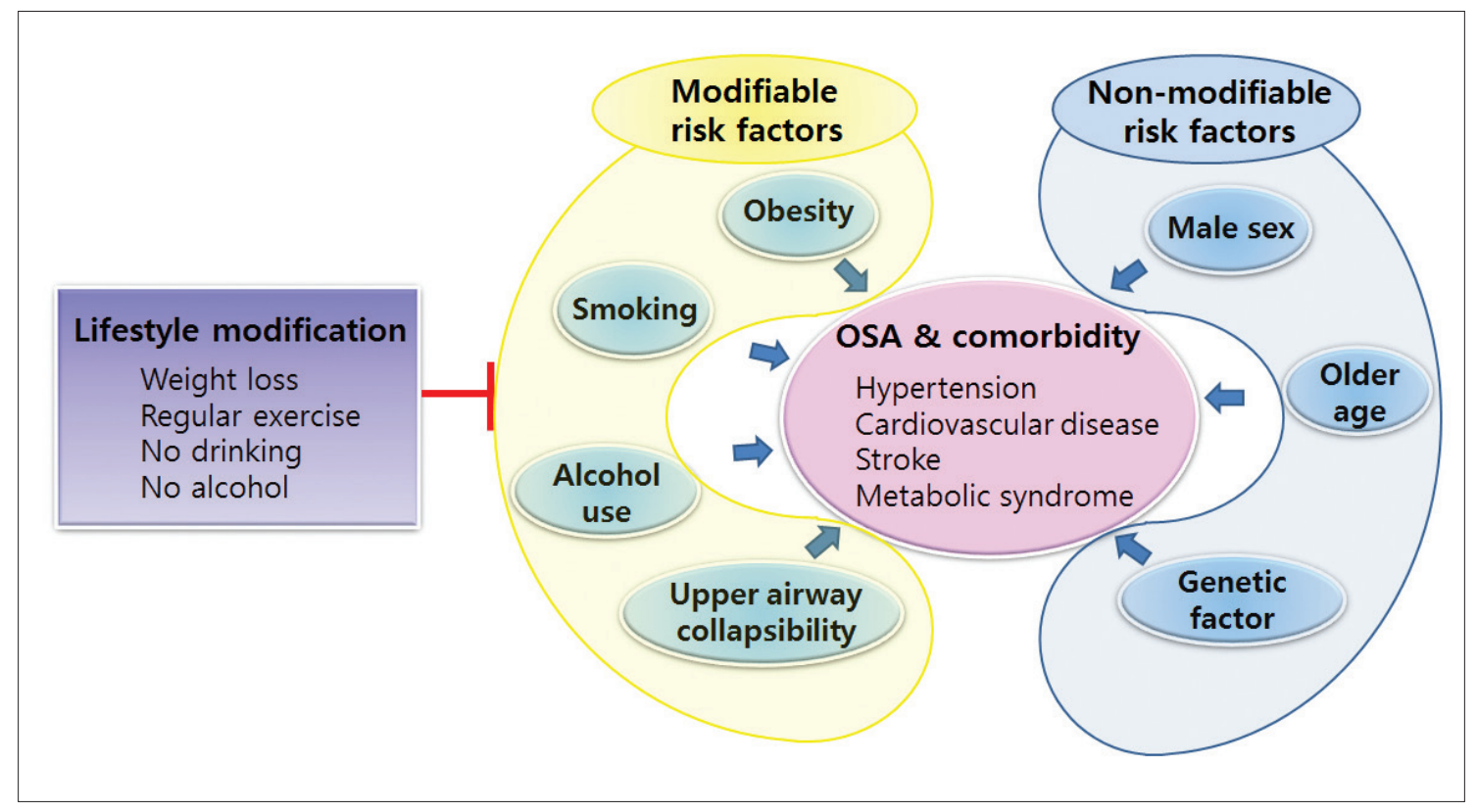

Fig. 1. Risk factors of OSA. A variety of risk factors of OSA, such as obesity, alcohol, smoking, upper airway collapsibility can be improved by lifestyle modifications. OSA: obstructive sleep apnea. 


\section{CONSTRUCTION AND USE OF LIFELOG DATA USING SMART DEVICES}

Various research has been carried out to solve this problem, and developments in mobile technology have led to the creation of a user-oriented smartphone or wearable device app related to activity tracking $[47,48]$. Using these apps, each individual can easily record and confirm information about his or her dietary intake, physical activity, and sleep. Furthermore, by linking the hospital's electronic medical record (EMR) with the smartphone app, a system is created that can summarize and present the patient's lifestyle information, such as dietary intake, physical activity, sleep, and stress on the physician's EMR screen [49]. That data is the life log data, which is the sum of the patient's lifestyle information and the hospital's clinical data, easily and conveniently constructed using the smart device and used in the medical environment.

With this system, doctors can check items such as dietary intake and physical activity during treatment through the lifestyle summary, and encourage additional lifestyle improvements based on the patient's actual life data in the clinic. Enabling patients to schedule and coordinate activities and set diet goals for the next hospital visit can motivate the patients to evaluate his or her lifestyle data with their doctor using the hospital EMR, and is much more effective than examining it alone on their smartphone. That is, with the use of EMR-linked smartphone apps, it is now possible to boost the effectiveness of lifestyle modification [50]. In a lifestyle modification study of patients with OSA using the above system for 4 weeks, BMI was significantly lower in the experimental group that used an EMR-linked smartphone app than in the control group, and a significant improvement was shown in the lowest oxygen saturation levels and percentage of sleep time snoring at $>45 \mathrm{~dB}$ [50].

\section{CONCLUSIONS}

In the treatment of OSA, physicians are aware of the need for lifestyle modifications, but often fail to recommend them for patients using CPAP, intraoral devices, and surgery due to constraints of treatment time. Additionally, the medical staff may overlook or underestimate the effectiveness of lifestyle modification on OSA. However, considering the treatment effect that can be obtained through weight loss and exercise and the adverse effects of smoking and alcohol on OSA, lifestyle modification is the most basic and necessary treatment in the entire treatment course of OSA. As such, possible benefits of the lifestyle modification should be explained to the patients. In addition, efforts should be made to improve lifestyle using smart devices that are easily accessible to patients in real life, and the results of which can be discussed together with doctors in a treatment environment. The use of smart devices represents an improvement over the traditional method based on private counseling, which is time consuming and costly both to patients and medical staff.

\section{Acknowledgments}

This work was partly supported by the Bio \& Medical Technology Development Program of the National Research Foundation (NRF) funded by the Korean government (MSIT) (No. NRF-2015M3A9D7066973) and by the Creative Industrial Technology Development Program (10053249, Development of Personalized Healthcare System exploiting User Life-Log and Open Government Data for Business Service Model Proof on Whole Life Cycle Care), funded by the Ministry of Trade, Industry \& Energy (MOTIE, Korea).

\section{Conflicts of Interest}

The authors have no financial conflicts of interest.

\section{Authors' Contribution}

Conceptualization: Kim JW. Data curation: Kim JW. Formal analysis: Kim JW. Funding acquisition: Kim JW. Methodology: Kim JW. Project administration: Kim JW. Resources: Lim HJ, Kim JW. Software: Lim HJ. Supervision: Kim JW. Validation: Kim JW. Visualization: Lim HJ. Writingoriginal draft: Lim HJ. Writing—review \& editing: Kim JW.

\section{REFERENCES}

1. Peppard PE, Young T, Palta M, Skatrud J. Prospective study of the association between sleep-disordered breathing and hypertension. $N$ Engl J Med 2000;342:1378-84.

2. Punjabi NM, Caffo BS, Goodwin JL, Gottlieb DJ, Newman AB, O'Connor GT, et al. Sleep-disordered breathing and mortality: a prospective cohort study. PLoS Med 2009;6:e1000132.

3. Lal C, Strange C, Bachman D. Neurocognitive impairment in obstructive sleep apnea. Chest 2012;141:1601-10.

4. Peppard PE, Szklo-Coxe M, Hla KM, Young T. Longitudinal association of sleep-related breathing disorder and depression. Arch Intern Med 2006;166:1709-15.

5. Tzischinsky O, Cohen A, Doveh E, Epstein R, Ribak J, Klein D, et al. Screening for sleep disordered breathing among applicants for a professional driver's license. J Occup Environ Med 2012;54:1275-80.

6. Schwartz AR, Patil SP, Squier S, Schneider H, Kirkness JP, Smith PL. Obesity and upper airway control during sleep. J Appl Physiol (1985) 2010;108:430-5.

7. Peppard PE, Young T, Palta M, Dempsey J, Skatrud J. Longitudinal study of moderate weight change and sleep-disordered breathing. JAMA 2000;284:3015-21.

8. Veasey SC, Guilleminault C, Strohl KP, Sanders MH, Ballard RD, Magalang UJ. Medical therapy for obstructive sleep apnea: a review by the Medical Therapy for Obstructive Sleep Apnea Task Force of the Standards of Practice Committee of the American Academy of Sleep Medicine. Sleep 2006;29:1036-44.

9. Kushida CA, Littner MR, Hirshkowitz M, Morgenthaler TI, Alessi CA, Bailey D, et al. Practice parameters for the use of continuous and bilevel positive airway pressure devices to treat adult patients with sleeprelated breathing disorders. Sleep 2006;29:375-80.

10. Sawyer AM, Gooneratne NS, Marcus CL, Ofer D, Richards KC, Weaver TE. A systematic review of CPAP adherence across age groups: clinical and empiric insights for developing CPAP adherence interventions. Sleep Med Rev 2011;15:343-56.

11. Ng SSS, Chan RSM, Woo J, Chan TO, Cheung BHK, Sea MMM, et al. A randomized controlled study to examine the effect of a lifestyle mod- 
ification program in OSA. Chest 2015;148:1193-203.

12. Kuna ST, Reboussin DM, Borradaile KE, Sanders MH, Millman RP, Zammit G, et al. Long-term effect of weight loss on obstructive sleep apnea severity in obese patients with type 2 diabetes. Sleep 2013;36: 641-9.

13. Tuomilehto H, Gylling H, Peltonen M, Martikainen T, Sahlman J, Kokkarinen J, et al. Sustained improvement in mild obstructive sleep apnea after a diet- and physical activity-based lifestyle intervention: postinterventional follow-up. Am J Clin Nutr 2010;92:688-96.

14. Nerfeldt P, Nilsson BY, Mayor L, Uddén J, Friberg D. A two-year weight reduction program in obese sleep apnea patients. J Clin Sleep Med 2010;6:479-86.

15. Tuomilehto HP, Seppä JM, Partinen MM, Peltonen M, Gylling H, Tuomilehto JO, et al. Lifestyle intervention with weight reduction: firstline treatment in mild obstructive sleep apnea. Am J Respir Crit Care Med 2009;179:320-7.

16. Foster GD, Borradaile KE, Sanders MH, Millman R, Zammit G, Newman $\mathrm{AB}$, et al. A randomized study on the effect of weight loss on obstructive sleep apnea among obese patients with type 2 diabetes: the Sleep AHEAD study. Arch Intern Med 2009;169:1619-26.

17. Johansson K, Neovius M, Lagerros YT, Harlid R, Rössner S, Granath F, et al. Effect of a very low energy diet on moderate and severe obstructive sleep apnoea in obese men: a randomised controlled trial. $B M J$ 2009;339:b4609.

18. Anandam A, Akinnusi M, Kufel T, Porhomayon J, El-Solh AA. Effects of dietary weight loss on obstructive sleep apnea: a meta-analysis. Sleep Breath 2013;17:227-34.

19. Sahlman J, Seppä J, Herder C, Peltonen M, Peuhkurinen K, Gylling H, et al. Effect of weight loss on inflammation in patients with mild obstructive sleep apnea. Nutr Metab Cardiovasc Dis 2012;22:583-90.

20. Romero-Corral A, Caples SM, Lopez-Jimenez F, Somers VK. Interactions between obesity and obstructive sleep apnea: implications for treatment. Chest 2010;137:711-9.

21. Mendelson M, Lyons OD, Yadollahi A, Inami T, Oh P, Bradley TD. Effects of exercise training on sleep apnoea in patients with coronary artery disease: a randomised trial. Eur Respir J 2016;48:142-50.

22. Servantes DM, Pelcerman A, Salvetti XM, Salles AF, de Albuquerque PF, de Salles FC, et al. Effects of home-based exercise training for patients with chronic heart failure and sleep apnoea: a randomized comparison of two different programmes. Clin Rehabil 2012;26:45-57.

23. Sengul YS, Ozalevli S, Oztura I, Itil O, Baklan B. The effect of exercise on obstructive sleep apnea: a randomized and controlled trial. Sleep Breath 2011;15:49-56.

24. Kline CE, Crowley EP, Ewing GB, Burch JB, Blair SN, Durstine JL, et al. The effect of exercise training on obstructive sleep apnea and sleep quality: a randomized controlled trial. Sleep 2011;34:1631-40.

25. Norman JF, Von Essen SG, Fuchs RH, McElligott M. Exercise training effect on obstructive sleep apnea syndrome. Sleep Res Online 2000;3: 121-9.

26. Iftikhar IH, Kline CE, Youngstedt SD. Effects of exercise training on sleep apnea: a meta-analysis. Lung 2014;192:175-84.

27. Aiello KD, Caughey WG, Nelluri B, Sharma A, Mookadam F, Mookadam M. Effect of exercise training on sleep apnea: a systematic review and meta-analysis. Respir Med 2016;116:85-92.

28. Haxhiu MA, van Lunteren E, Mitra J, Cherniack NS, Strohl KP. Comparison of the responses of the diaphragm and upper airway muscles to central stimulation of the sciatic nerve. Respir Physiol 1984;58:65-76.

29. O’Donnell DE, McGuire M, Samis L, Webb KA. General exercise training improves ventilatory and peripheral muscle strength and endurance in chronic airflow limitation. Am J Respir Crit Care Med 1998;157(5 Pt 1):1489-97.

30. Mirrakhimov AE. Physical exercise related improvement in obstructive sleep apnea. Look for the rostral fluid shift. Med Hypotheses 2013;80: 125-8.
31. Baik I, Seo HS, Yoon D, Kim SH, Shin C. Associations of sleep apnea, NRG1 polymorphisms, alcohol consumption, and cerebral white matter hyperintensities: analysis with genome-wide association data. Sleep 2015;38:1137-43.

32. Pan Y, Wang W, Wang KS. Associations of alcohol consumption and chronic diseases with sleep apnea among US adults. Int $J$ High Risk Behav Addict 2014;3:e19088.

33. Kang K, Seo JG, Seo SH, Park KS, Lee HW. Prevalence and related factors for high-risk of obstructive sleep apnea in a large Korean population: results of a questionnaire-based study. J Clin Neurol 2014;10:42-9.

34. Peppard PE, Austin D, Brown RL. Association of alcohol consumption and sleep disordered breathing in men and women. J Clin Sleep Med 2007;3:265-70.

35. Taasan VC, Block AJ, Boysen PG, Wynne JW. Alcohol increases sleep apnea and oxygen desaturation in asymptomatic men. Am J Med 1981; 71:240-5.

36. Scanlan MF, Roebuck T, Little PJ, Redman JR, Naughton MT. Effect of moderate alcohol upon obstructive sleep apnoea. Eur Respir J 2000;16: 909-13.

37. Simou E, Britton J, Leonardi-Bee J. Alcohol and the risk of sleep apnoea: a systematic review and meta-analysis. Sleep Med 2018;42:38-46.

38. Krol RC, Knuth SL, Bartlett D Jr. Selective reduction of genioglossal muscle activity by alcohol in normal human subjects. Am Rev Respir Dis 1984;129:247-50.

39. Robinson RW, White DP, Zwillich CW. Moderate alcohol ingestion increases upper airway resistance in normal subjects. Am Rev Respir Dis 1985;132:1238-41.

40. Landolt HP, Roth C, Dijk DJ, Borbély AA. Late-afternoon ethanol intake affects nocturnal sleep and the sleep EEG in middle-aged men. $J$ Clin Psychopharmacol 1996;16:428-36.

41. Ye R, Yang W, Yuan Y, Deng X. The CC genotype of the delta-sarcoglycan gene polymorphism rs 13170573 is associated with obstructive sleep apnea in the Chinese population. PLoS One 2014;9:e114160.

42. Koyama RG, Esteves AM, Oliveira e Silva L, Lira FS, Bittencourt LR, Tufik S, et al. Prevalence of and risk factors for obstructive sleep apnea syndrome in Brazilian railroad workers. Sleep Med 2012;13:1028-32.

43. Kashyap R, Hock LM, Bowman TJ. Higher prevalence of smoking in patients diagnosed as having obstructive sleep apnea. Sleep Breath 2001; 5:167-72.

44. Wetter DW, Young TB, Bidwell TR, Badr MS, Palta M. Smoking as a risk factor for sleep-disordered breathing. Arch Intern Med 1994;154: 2219-24.

45. Krishnan V, Dixon-Williams S, Thornton JD. Where there is smoke... there is sleep apnea: exploring the relationship between smoking and sleep apnea. Chest 2014;146:1673-80.

46. Kim KS, Kim JH, Park SY, Won HR, Lee HJ, Yang HS, et al. Smoking induces oropharyngeal narrowing and increases the severity of obstructive sleep apnea syndrome. J Clin Sleep Med 2012;8:367-74.

47. Martin CK, Miller AC, Thomas DM, Champagne CM, Han H, Church T. Efficacy of SmartLoss, a smartphone-based weight loss intervention: results from a randomized controlled trial. Obesity (Silver Spring) 2015; 23:935-42.

48. Rogers RJ, Lang W, Barone Gibbs B, Davis KK, Burke LE, Kovacs SJ, et al. Applying a technology-based system for weight loss in adults with obesity. Obes Sci Pract 2016;2:3-12.

49. Ryu B, Kim N, Heo E, Yoo S, Lee K, Hwang H, et al. Impact of an electronic health record-integrated personal health record on patient participation in health care: development and randomized controlled trial of MyHealthKeeper. J Med Internet Res 2017;19:e401.

50. Cho SW, Wee JH, Yoo S, Heo E, Ryu B, Kim Y, et al. Effect of lifestyle modification using a smartphone application on obesity with obstructive sleep apnea: a short-term, randomized controlled study. Clin Exp Otorhinolaryngol 2018;11:192-8. 